\title{
Etyczne aspekty stosowania psychologii w przestrzeni życia religijnego
}

\section{ETHICAL ASPECTS OF THE USE OF PSYCHOLOGY IN THE AREA OF RELIGIOUS LIFE}

The main aim of this paper is to present the contribution of psychology in the area of religious life and to vocational discernment and christian formation. The vocation to the priesthood and its discernment lie outside the strict competence of psychology. In some cases, recourse to experts in the psychological sciences can be useful. It can allow a more sure evaluation of the candidate's psychic state. It can help evaluate his human dispositions for responding to the divine call and it can provide some extra assistance for the candidate's human growth. The use of psychology and psychotherapy must be combined necessarily with compliance with fundamental ethical principles. In particular, the current challenge is now to respect ethical principles in the context of new forms of psychological manipulation, which appear today in various forms of religious life.

Key words: anthropology, depth psychology, ethical principles, pentecostalization, psychoanalytic methods, psychological manipulation.

\section{Wprowadzenie}

Dnia 12 marca 2015 roku Konferencja Episkopatu Polski wydała dekret zakazujący sprawowania tzw. spowiedzi furtkowej i praktykowania 
rachunku sumienia w oparciu o koncepcję furtek złego ducha. Ta osobliwa praktyka religijna, odwołująca się do niektórych form religijności zielonoświątkowej oraz do antropologii i kosmologii typowej dla mentalności Czarnego Lądu, przypomina w swej istocie afrykańską koncepcję obecności w świecie różnego rodzaju duchów i ich potężnej władzy nad życiem człowieka. Nowa forma praktykowania rachunku sumienia i sakramentu pojednania - w ostatnich kilku latach zmodyfikowana i „udoskonalona” w dużym stopniu przez niektórych księży na Mazowszu - rozprzestrzeniła się w wielu środowiskach katolickich w Polsce i na świecie.

Spór antropologiczny, teologiczny i etyczny o furtki złego ducha zawiera w sobie także pytanie o zasady moralne, które powinny regulować funkcjonowanie różnego rodzaju grup religijnych czy wspólnot modlitewnych. Co wolno duchownym różnych wyznań w stosunku do członków ich wspólnot wyznaniowych? Jakie zasady etyczne powinny obowiązywać w relacji duchownych i liderów religijnych wobec osób, za które są odpowiedzialni? W jaki sposób przekazywać treści o charakterze religijnym, których prawdziwość trudno zweryfikować naukowo? Jak unikać, w różnego rodzaju praktykach religijnych, działań i zachowań, które mogą być, z różnych racji, szkodliwe dla zdrowia fizycznego i psychicznego ludzi?

Niestety, działalności liderów wspólnot i ruchów religijnych nie regulują dzisiaj de facto jakiekolwiek kodeksy etyczne. W konsekwencji w wielu krajach - w różnego rodzaju kościołach, związkach wyznaniowych i sektach - dość często dochodzi do tego, że niektórzy liderzy religijni przejmują władzę psychiczną nad członkami swoich wspólnot, stosują niedozwolone środki psychomanipulacji, niesprawdzone bądź fałszywe treści religijne przekazują jako pewne i prawdziwe, ograniczają indywidualną wolność swoich wyznawców i zbyt głęboko wpływają na ich osobiste decyzje itd.

Wykorzystywanie różnego rodzaju wiedzy psychologicznej i metod psychoterapeutycznych w przestrzeni życia religijnego wymaga także przejrzystych zasad etycznych. Jakie formy psychoterapii wolno wprowadzać do praktyk religijnych? Jak nie utożsamiać religii z psychologią i psychologii z religią? Jakie nurty psychologii i psychoterapii pozostają w zgodzie z chrześcijańską wizją człowieka czy światopoglądem katolickim? Jaką antropologię zakłada psychoanaliza? Jak oceniać psychoterapię o charakterze psychoanalitycznym, którą czasami stosuje się w niektórych środowiskach katolickich nad Wisłą i łączy np. $\mathrm{z}$ różnego rodzaju rekolekcjami? 
Celem artykułu jest ukazanie kilku wybranych problemów etycznych, związanych ze stosowaniem psychologii i psychoterapii w przestrzeni życia religijnego ${ }^{1}$. Wydaje się, że tego rodzaju kwestie są dzisiaj bardzo aktualne w Polsce w wielu seminariach duchownych, wspólnotach życia zakonnego, ruchach religijnych, duszpasterstwie akademickim czy duszpasterstwie parafialnym.

\section{Psychologizacja religii}

W styczniu 2013 roku porzucił kapłaństwo i życie zakonne o. Jacek Krzysztofowicz OP. Ten znany w całej Polsce duchowny pracował także jako terapeuta w dominikańskim Ośrodku Pomocy Psychologicznej w Gdańsku. W bardzo licznych komentarzach medialnych, dotyczących decyzji podjętej na początku 2013 roku przez tego cenionego dominikanina, pojawiło się wiele ciekawych wątków. Niektóre z nich były związane z oceną jednej z metod psychoterapii, która odwołuje się do koncepcji ustawień rodzinnych niemieckiego psychologa i psychoterapeuty Berta Hellingera. Inne głosy w dyskusji dotyczyły m.in. relacji istniejącej między psychologią i religią oraz tzw. psychologizacji religii. Niewątpliwie ta ostatnia kwestia staje się dzisiaj poważnym wyzwaniem duchowym i intelektualnym dla chrześcijan różnych nurtów i denominacji. Psychologizacja religii odnosi się do współczesnego pojęcia duchowości i religii bez Boga czy Transcendencji.

Istnieje nurt psychologii religii - twierdzi włoski autor Mario Aletti - który ma swoje korzenie w pismach Williama Jamesa oraz swoją formę wyrazu w pojęciu „religii humanistycznej” Ericha Fromma, ale częściowo także w idei „absolutów zastępczych” Gordona Allporta, która ma wpływ na pojęcie „doświadczenia religijnego”. Tego rodzaju ujęcie doświadczenia religijnego podkreśla emocje i „uczucie religijne”, otwierając w ten sposób drogę do współczesnego pojęcia duchowości lub religii bez Transcendencji/Boga oraz do tzw. psychologizacji religii (la psicologizzazione della religione), tzn. do redukowania religii do subiektywnego doświadczenia „duchowości”, w którym to, co duchowe,

Por. A. Valerio, Diventa ciò che sei. Un cammino di psicospiritualità cristiana, Cinisello Balsamo 2005; G. Lämmermann, Einführung in die Religionspsychologie, Neukirchen-Vluyn 2006; B. Grom, Religionspsychologie, München 2007; J.R.Prada Ramirez, Psicologia eformazione. Principi psicologiciutilizzati nella formazione peril sacerdozio e la vita consacrata, Roma 2009; W. Vial, Psicologia e vita cristiana. Cura della salute mentale e spirituale, Roma 2012; S. De Simone, Premesse e promesse dell'esperienza credente cristiana. Una ricomprensione dell',Analysis fidei" a partire dal rapporto tra teologia della grazia e psicologia, Assisi 2015; J. A. Belzen, Religionspsychologie. Eine historische Analyse im Spiegel der Internationalen Gesellschaft, Berlin - Heilderberg 2015. 
Teologia pastoralna

dąży do roztopienia się w szerszych ramach sfery psychicznej (lo spirituale tende a svanire nei più ampi contorni dello psichico) $)^{2}$.

Problem psychologizacji religii pojawia się w oficjalnym nauczaniu Kościoła katolickiego m.in. w opracowaniu z 2003 roku dotyczącym ruchu New Age $^{3}$. Dokument ten został przygotowany przez Papieską Radę ds. Kultury i Papieską Radę ds. Dialogu Międzyreligijnego, przy współpracy Kongregacji ds. Ewangelizacji Narodów oraz Papieskiej Rady ds. Popierania Jedności Chrześcijan. W dokumencie czytamy, że duchowość New Age jest poszukiwaniem wewnętrznej harmonii i jedności z całym kosmosem. Człowiek ma odkryć, że jest ściśle powiązany z Uniwersalną Mocą czy Energią, która jest święta i stanowi źródło wszelkiego życia. To doświadczenie jedności ma uzdrowić człowieka z wszelkiej niedoskonałości czy ograniczoności. Doskonałość zaś pojmowana jest jako doprowadzenie do pełni własnego ,ja”, zgodnie z systemem wartości, które człowiek sam sobie stworzy.

Ruch New Age traktuje człowieka jako boga, zaś na pytanie, dlaczego ludzie nie uświadamiają sobie swojej boskości, odpowiada, iż przyczyną jest niewiedza. Zdaniem propagatorów tego ruchu, nasza kultura wykształciła w nas ograniczenia, wpoiła pojęcie grzeszności i skończoności. To sprawiło, iż człowiek zapomniał, kim jest, zapomniał, że jest bogiem. Aby osiągnąć pożądany stan boskości, człowiek musi włożyć wiele wysiłku w samodoskonalenie się. Tu naprzeciw wychodzą propagatorzy różnego rodzaju kursów doskonalenia umysłu, odkrywania nieograniczonego potencjału ludzkiego czy innych technik prowadzących do tzw. zmiany świadomości. Stosowanie różnego rodzaju technik w celu doskonalenia siebie ma doprowadzić do powszechnej zmiany naszego sposobu myślenia, zmiany spojrzenia na świat, wreszcie do nowego sposobu widzenia rzeczy ${ }^{4}$.

$2 \quad$ M.Aletti, Il senso religioso ela psicologia della religione. Decostruire un concetto, elaborare un metodo, proporre strumenti, [w:] M. T. Moscato, R. Gatti, M. Caputo (red.), Crescere tra vecchi e nuovi dei. L'esperienza religiosa in prospettiva multidisciplinare, Roma 2012, s. 270. „Di qui la duplice scelta della maggior parte dei psicologi della religione: a) di considerare non la religione nella sua essenza, ma il funzionamento psichico della persona nei confronti di una specifica forma religiosa oggettivamente rilevabile in una cultura, e b) di riservare il concetto di religione a quelle forme che fanno riferimento ad un essere che è ritenuto trascendente e divino. La consapevolezza di questo riferimento intenzionale e l'assenso prestatovi sarebbero costitutivi della religione e la distinguerebbero dalla generica spiritualità (ibidem)". Por. M. Aletti (red.), Psicologia della religione. Prospettive psicosociali ed empiriche, Torino 2001.

3 Papieska Rada ds. Kultury, Papieska Rada ds. Dialogu Międzyreligijnego, Jezus Chrystus dawca wody żywej. Refleksja chrześcijańska nt. New Age, Poznań 2003.

Ibidem, s. 30-33. Por. P. McGuire, Jak ewangelizować New Age?, Toruń 1995. 
Jednym z ważnych prekursorów New Age był szwajcarski psycholog Carl Gustaw Jung, który podkreślał transcendentalny charakter świadomości i wprowadził ideę nieświadomości kolektywnej - rodzaj magazynu symboli i wspomnień wspólnych dla ludzi w różnym wieku i z różnych kultur ${ }^{5}$. Jung przyczynił się do „sakralizacji psychologii” przez wprowadzenie do niej elementów ezoterycznych spekulacji. W konsekwencji ludzie mówią o Bogu, mając na myśli ich własną psychikę, i mówią o swojej własnej psychice, myśląc w rzeczywistości o boskości. Jeśli psychika jest „umysłem” i również Bóg jest „umysłem", wówczas mówiąc o jednym nie można równocześnie nie mówić o drugim.

\section{Psychologia głębi}

Carl Gustaw Jung jest m.in. autorem terminu „psychologia głębi” (niem. Tiefenpsychologie), który określa różne koncepcje psychologiczne, wywodzące się genetycznie z psychoanalizy Sigmunda Freuda, lecz znacznie się od niej różniące. Koncepcje te stanowią teoretyczne zaplecze dla różnych form psychoterapii (niekoniecznie psychoanalitycznych). Wspólnym elementem różnych szkół psychologii głębi są kategorie podświadomości i nieświadomości oraz założenie, że są to sfery ludzkiej psychiki znajdujące się w ukryciu, do których dostęp jest możliwy przy pomocy psychoterapii. Psychoterapia jest w psychologii głębi metodą hermeneutyczną polegającą na interpretowaniu snów, swobodnych skojarzeń, przejęzyczeń i konfabulacji badanej czy też terapeutyzowanej osoby.

Możliwość wykorzystania psychologii głębi w kręgach katolickich stała się w latach sześćdziesiątych ubiegłego wieku przedmiotem badań włoskiego jezuity Luigiego Rulli. W 1971 roku stworzył on Instytut Psychologii na Papieskim Uniwersytecie Gregoriańskim w Rzymie $^{6}$. Należy zauważyć, że w tamtym okresie wielu innych autorów, szczególnie psychologów amerykańskich (Elizabeth Liebert, Richard Sweeney, Morton Kelsey), próbowało łączyć metody psychoanalityczne z chrześcijaństwem. Specyfiką badań Rulli było wykorzystanie metod psychoanalitycznych oraz odwoływanie się do tomizmu transcendentalnego belgijskiego intelektualisty Josepha Maréchala, który w drugiej połowie XX wieku był bardzo ważnym nurtem myśli filozoficznej i teologicznej na Papieskim Uniwersytecie Gregoriańskim w Rzymie.

Por. Z. W. Dudek, Podstawy psychologii Junga, Warszawa 2009.

Por. S. Morgalla, Dojrzatość osobowościowa i religijna. Luigi Maria Rulla i jego teorie psychologiczne oraz poglady antropologiczne, Kraków 2006. 
Teologia pastoralna

Rulla opierał swoją refleksję intelektualną głównie na analizach kanadyjskiego filozofa i teologa Bernarda Lonergana, który twórczo rozwijał dzieło Maréchala ${ }^{7}$.

Rulla wypracował pierwszą psycho-społeczną teorię powołania chrześcijańskiego. Tworzył zręby swojej koncepcji psychologicznej i psychoterapeutycznej w klimacie rewolucji seksualnej 1968 roku oraz w dobie kryzysu Kościoła katolickiego, jaki rozpoczął się w wielu krajach świata po Vaticanum II. W tym czasie w niektórych kręgach katolickich - w atmosferze ogólnego zagubienia i głębokiego zamieszania, przy dziesiątkach tysięcy księży, zakonników i zakonnic porzucających służbę Bożą w Kościele - dostrzeżono pilną konieczność głębszego zrozumienia podstawowych procesów psychologicznych, mających wpływ na odkrycie i realizację powołania kapłańskiego i zakonnego ${ }^{8}$.

W oparciu o psychologię głębi, w drugiej połowie lat sześćdziesiątych ubiegłego wieku, Rulla prowadził badania empiryczne oraz wywiady wśród amerykańskich duchownych i seminarzystów. Dążył do postawienia adekwatnej diagnozy, gdy chodzi o wybór drogi powołania, realizację i ewentualne porzucenie drogi życia zakonnego czy kapłańskiego. Badania Rulli pokazały, że od $60 \%$ do $80 \%$ księży i zakonników kierowało się motywami podświadomymi przy wyborze swej drogi życiowej. Przy podejmowaniu decyzji sugerowali się oni zasadniczo tym, jak unikać czegoś bądź jak zaspokajać pewne potrzeby ${ }^{9}$. Owocem

$7 \quad$ Por. E. B. Howard, Affirming the Touch of God: A Psychological and Philosophical Exploration of Christian Discernment, Lanham 2000, s. 40; B. Lonergan, Insight: A Study of Human Understanding, t. I-III, Toronto 1992.

8 P. Egenolf, Vocation and Motivation. The Theories of Luigi Rulla, „The Way” 42 (2003) 3, s. 81-93. ,We need to bear in mind the other basic human characteristic which Rulla names. Humanity is not simply endowed with the capacity for theocentric self-transcendence and with the quality of freedom that this entails; it is also in many ways finite, limited. And these limitations can restrict to a greater or lesser extent human freedom for self-transcendence towards God. Thus Christian vocation occurs within a fundamental tension or dialectic, shaped by two opposing tendencies: a capacity for self-transcendence fostering human partnership with God, and a limitation on freedom that can impair this partnership. The programmes of formation that were set in place after Vatican II did not, for Rulla, pay enough attention to these limitations. Rulla is concerned to put forward an account of Christian vocation that does justice to both sides of the tension: to what a person should be and what they actually are. Thus Rulla presents his account as a mediating position between two extremes, both of which are in danger of oversimplifying what a human being is" (ibidem, s. 84).

„According to Rulla's researches, between $60 \%$ and $80 \%$ of priests and religious are influenced by unconscious inconsistencies. Typical manifestations of this are stereotypical styles of behaviour inappropriate to the real situation; uncontrolled projections; the inability to change one's behaviour even given 
wieloletnich badań włoskiego jezuity była książka Psychologia głębi i powołanie. Perspektywa psycho-społeczna, która ukazała się w języku angielskim w $1971 \mathrm{roku}^{10}$.

Wydaje się, że propozycje Rulli wymagają dzisiaj wnikliwej analizy, aby lepiej zrozumieć szerszy kontekst kulturowy lat sześćdziesiątych i siedemdziesiątych ubiegłego wieku. Być może nie wszystkie ustalenia i propozycje Rulli są obecnie aktualne? W Polsce, z jednej strony, $\mathrm{w}$ wielu środowiskach katolickich - w tym w wielu seminariach duchownych i wspólnotach zakonnych męskich i żeńskich - korzysta się z różnych form psychoterapii odwołujących się do koncepcji tego autora, z drugiej - właściwie nie ma publikacji w naszym języku, które by poddawały dzieło Rulli głębszej analizie krytycznej, szczególnie w kontekście nowych badań nad szeroko rozumianą psychoanalizą, prowadzonych w wielu krajach na przestrzeni ostatnich kilkudziesięciu lat, które zwracają uwagę na błędy i ograniczenia psychoanalitycznej wizji człowieka ${ }^{11}$.

\section{Sigmund Freud czy Romano Guardini?}

29 listopada 1993 roku ukazał się w USA oraz na całym świecie nowy numer magazynu „Time”. Na okładce tego pisma umieszczono twarz Sigmunda Freuda ułożoną z rozpadających się puzzli. Temu niezwykle

good insight into the situation and a ready will. These restrictions on human maturity impede spiritual growth and apostolic effectiveness" (ibidem, s. 87).

10 Por. L. Rulla, Depth psychology and vocation. A psicho-social perspective, Roma 1971. Najważniejszym opracowaniem tego autora jest trzy tomowe dzieło Antropologia powołania chrześcijańskiego. Por. idem, Antropologia della vocazione cristiana, t. I, Basiinterdisciplinari, Bologna 1986; Antropologia della vocazione cristiana, t.II, Conferme esistenziali, Bologna 1989; Antropologia della vocazione cristiana, t. III, Aspetti interpersonali, Bologna 1998.

11 Por. G. Magnani, La crisi della metapsicologia freudiana, Roma 1981. „Il rigetto della metapsicologia non può (...) interpretarsi come rigetto di ogni teoria né dell'intera teoria generale psicoanalitica come è in Freud, ma molto meno come è nella psicologia dell'io e nelle varianti concernenti il narcinismo e la teoria del Self. Tuttavia l'abbandono della metapsicologia lascia aperta una ristrutturazione della teoria psicologica, esistente solo a tratti non coordinati e per la quale (...) sono per ora presenti non più che tentativi o semiparadigmi. Forse, ma non è ancora chiaro, essi sono coordinabili, almeno per una certa sezione della psicologia dell'io americana. Restano aperti molti problemi, che vanno dal riconoscimento della necessità di un riferimento filosofico specie per il rapporto mente-corpo, a quello di una risistemazione ulteriore sul conscio, sul Self e sulla persona; si può sperare che la liberazione dal riduzionismo positivista possa condurre a una migliore considerazione di quest'ultima anche all'interno della scuola freudiana" (ibidem, s. 261-261). 
wymownemu obrazowi towarzyszył napis: „IS FREUD DEAD?”. Artykuły opublikowane $\mathrm{w}$ tym numerze amerykańskiego tygodnika - poświęcone m.in. kłamstwom ludzkiego umysłu w tzw. Repressed-Memory Therapy - rozpoczęły ciekawą i niezwykle inspirującą debatę filozoficzną, psychologiczną i psychoterapeutyczną w wielu krajach świata. Z poważną dyskusją na temat blasków i cieni psychoanalizy można się było spotkać w tym czasie m.in. na Papieskim Uniwersytecie Gregoriańskim w Rzymie.

Jednym z kluczowych problemów w ocenie różnych koncepcji psychologicznych i psychoterapeutycznych, odwołujących się do idei psychoanalitycznych Freuda, jest kwestia antropologiczna. Ojciec psychoanalizy opowiadał się za typowo pozytywistyczną wizją człowieka, w której bycie jednostki ludzkiej zostaje zasadniczo zredukowane do sfery biologicznej i popędowej. W systemie myślowym Freuda nie ma miejsca na wizję człowieka jako osoby, w której akcentuje się harmonię tego, co cielesne z tym, co duchowe i psychiczne. Antropologia ojca psychoanalizy jest radykalnym zakwestionowaniem chrześcijańskiej wizji człowieka jako „ducha wcielonego” czy „ciała uduchowionego”.

Kwestia antropologiczna jest niewątpliwie największym ograniczeniem koncepcji Freuda. Rzetelna wiedza psychologiczna o człowieku i adekwatne modele psychoterapii muszą opierać się o właściwą antropologię. Jedną z najciekawszych koncepcji antropologicznych, wypracowanych w XX wieku, jest propozycja niemieckiego filozofa i teologa Romana Guardiniego, który był jednym z reprezentantów personalizmu dialogicznego. Niemiecki myśliciel tworzył zręby swojej teorii antropologicznej w latach dwudziestych i trzydziestych ubiegłego stulecia, naznaczonych tragiczną sytuacją kultury europejskiej. W tym okresie zanegowano w kulturze zachodniej tradycyjne sposoby rozumienia człowieka, wypracowane w przeszłości przez humanizm grecko-chrześcijański i naukę nowożytną. Przejawem tego kryzysu były dzieła takich myślicieli jak Charles Darwin, Ludwig Feuerbach, Karl Marx czy Sigmund Freud, którzy zakwestionowali antropologię, bazującą na człowieku jako bycie cielesno-duchowym.

Antropologia Guardiniego stanowi radykalne zaprzeczenie m.in. psychoanalitycznej wizji bytu ludzkiego. Niemiecki filozof i teolog twierdził, że odkrycia nauki nowożytnej spowodowały trzy wielkie upokorzenia człowieka. Na pierwszym miejscu należy postawić odkrycie Kopernika, że człowiek i jego ziemia nie stanowią centrum świata. Drugi szok został spowodowany teorią Darwina, zgodnie z którą człowiek nie jest stworzeniem Bożym, ale jedynie kaprysem natury i owocem ewolucji. Trzecie upokorzenie wywołało odkrycie Freuda dotyczące 
obecności w człowieku sił nieświadomych, które w znaczący sposób wpływają na nasze wolne decyzje ${ }^{12}$.

Antropologia Guardiniego obejmuje trzy różne poziomy refleksji: fenomenologiczną strukturę warstw, dedukcję dialogiczną i podstawę metafizyczną. Wszystkie trzy poziomy opierają się na przekonaniu, że człowiek jest $\mathrm{w}$ swej istocie osobą ${ }^{13}$. Pojęcie osoby jest pojęciem demokratycznym, ponieważ osobą jest każdy człowiek. Być człowiekiem oznacza być osobą ${ }^{14}$. W konsekwencji pojęcie osoby jest pojęciem rewolucyjnym, ponieważ zwraca się przeciw jakiejkolwiek formie przywileju. W pojęciu osoby zakorzenia się autentyczna równość między ludźmi: prawo do życia, prawo do wolności, prawo do szacunku, równość wobec prawa ${ }^{15}$.

Guardini odwoływał się do tradycji filozoficznej Platona i Arystotelesa, w której rzeczywistość nie jest skonstruowana w sposób jednorodny, ale są w niej do odkrycia różne poziomy jakościowe ${ }^{16}$. Idąc tym tropem, postrzegał człowieka jako istotę przepełnioną napięciem przeciwstawnych sił. Aktualizacja egzystencji jest określona przede wszystkim przez drogę, która prowadzi od tego, co niższe, w kierunku tego, co wyższe. W ten sposób dokonuje się dzieło uduchowienia i sublimacji. Całe życie człowieka zasadza się na przeciwieństwie, które polega na tym, że w strukturze żywego bytu realizuje się specyficzny stosunek dwóch elementów. Przeciwieństwo jest sposobem ludzkiego życia. Wszystko co jest żywe, posiada strukturę przeciwieństwa.

Niemiecki filozof i teolog wyodrębnił dwa szeregi przeciwieństw, na które składa się wiele par, ułożonych następnie w grupy i tworzących cały system. Jeden szereg jest wyrazem dynamiki, drugi natomiast reprezentuje element statyczny. Życie nie jest syntezą wszystkich tych

12 Por. A. Schilson, Welt und Person. Der geistesgeschichtliche Hintergrund. Perspektiven der Antropologie zu Beginn des 20 Jahrhunderts, „Burgbrief” (1991) 3, s. 10-11.

13 Por. R. Guardini, Ethik. Vorlesungen an der Universität München (1950-1962), t. I, Mainz - Padeborn 1993, s. 200.

14 „Der Begriff der Person ist ein ontologischer, kein kulturphilosophischer oder pädagogischer Begriff. Er richtet sich auf den Menschen als solchen, nicht auf seine Begabung und Leistung. Der Mensch als solcher ist Person; auch wenn er noch unbegabt, noch so ungebildet, noch zu farblos ist" (ibidem, s. 207).

15 Por. R. Guardini, L'esistenza del cristiano, Milano 1977, s. 405.

16 Por. L. Börsig-Hover, Das personale Antliz des Menschen. Eine Untersuchung zum Personbegriff bei Romano Guardini, Mainz 1987, s. 53-55; E. Biser, Chi era Romano Guardini? Domande rivolte a una risposta, [w:] S. Zucal (red.), Romano Guardini e la sua visione cristiana del mondo, Padova 1989, s. 32-33. 
przeciwieństw, nie jest ich zmieszaniem, ale jest specyficzną jednością, będącą związkiem dwoistości elementów.

Wydaje się, że tego rodzaju rozumienie człowieka jako jedności przeciwieństw ma dzisiaj niezwykle ważne znaczenie dla psychologii i psychoterapii. Z pewnością w wielu sytuacjach, gdy chodzi o pomoc psychologiczną i psychoterapeutyczną, lepiej skoncentrować się na akceptacji siebie jako jedności różnych przeciwstawnych sił i popędów, niż szukać w nieskończoność nieuświadomionych motywów naszych zachowań, z którymi czasami trzeba nauczyć się żyć. Pytanie o pod-

Teologia pastoralna stawy antropologiczne psychoterapii jest dzisiaj niezwykle aktualne m.in. w wielu polskich zakonach i seminariach duchownych.

\section{Wykorzystanie testów psychologicznych}

Jedną z najważniejszych rzeczy, jaką zawdzięczamy wiedzy psychologicznej jest badanie osobowości z opisem. Różne formy badania osobowości odgrywają niezwykle istotną rolę także w pracy nad sobą w ramach przygotowania do małżeństwa, kapłaństwa czy życia zakonnego. Problemem wielu ludzi jest dzisiaj tzw. brak wglądu w siebie. Jeśli ktoś miesza fikcję z rzeczywistością i nie ma realnej oceny siebie samego, nie jest w stanie podjąć skutecznej pracy nad sobą. Problem ten może zostać usunięty dzięki odpowiednim testom psychologicznym i badaniu osobowości z opisem. Przy stosowaniu tego rodzaju badań należy zachować podstawowe standardy etyczne,

Wykorzystanie różnego rodzaju badań psychologicznych i terapii psychologicznej ma dzisiaj charakter globalny. W Kościele katolickim zaczęto stosować kompetencje psychologiczne w procesie rozeznania powołania i formacji seminaryjnej oraz zakonnej w latach siedemdziesiątych ubiegłego wieku. Prekursorami w tym zakresie były niektóre środowiska katolickie w krajach anglosaskich. Od samego początku usiłowano wypracować zasady etyczne, którymi należy się kierować w tego rodzaju działaniach. W połowie lat siedemdziesiątych XX wieku Kongregacja Edukacji Katolickiej, na polecenie Sekretariatu Stanu, podjęła własne badania dotyczące wykorzystania psychologii w trakcie przyjmowania kandydatów do kapłaństwa i życia zakonnego oraz w procesie wychowawczym. 19 listopada 1975 roku ówczesny Sekretarz Stanu kard. Jean-Marie Villot skierował w tej sprawie specjalny list do Kongregacji Wychowania Katolickiego, do którego była dołączona Nota indicativa. Sekretariat Stanu Stolicy Apostolskiej zwrócił szczególną uwagę na konieczność obrony intymności osoby w obliczu możliwości 
różnego rodzaju naruszenia prywatności przy stosowaniu zdobyczy współczesnej psychologii i psychoterapii.

Po tym liście Sekretariatu Stanu Kongregacja Wychowania Katolickiego rozpoczęła prace nad przygotowaniem odpowiedniego dokumentu na temat wykorzystania różnego rodzaju badań psychologicznych i terapii psychologicznej. W prace nad dokumentem zostały włączone także trzy inne kongregacje: Kongregacja Doktryny Wiary, Kongregacja ds. Duchowieństwa i Kongregacja ds. Życia Zakonnego (obecnie Kongregacja ds. Instytutów Życia Konsekrowanego i Stowarzyszeń Życia Apostolskiego). Sekretariat Stanu polecił wówczas Kongregacji Nauki Wiary przygotowanie w tej sprawie odpowiedniej deklaracji, ale żadna z dykasterii rzymskich nie wypracowała dokumentu programowego. Prowadzone prace nad przygotowaniem odpowiedniego dokumentu na temat wykorzystania różnego rodzaju badań psychologicznych i terapii psychologicznej nie przyniosły spodziewanych owoców.

W konsekwencji od lat siedemdziesiątych XX wieku jedyną wypowiedzią oficjalną Kościoła katolickiego na ten temat była Nota indicativa Sekretariatu Stanu z 1975 roku. Znajdujemy w tym dokumencie m.in. dwa ważne kryteria wykorzystania psychologii w przygotowaniu kandydatów do kapłaństwa i życia zakonnego. Po pierwsze, nikomu z przełożonych zakonnych czy diecezjalnych nie wolno wkraczać w intymność psychologiczną czy moralną (intimità psicologica o morale) kleryków, księży, sióstr zakonnych czy braci zakonnych - nie mając uprzednio wyrażonej bezpośrednio przez nich zgody całkowicie świadomej (il previo, esplicito, informato ed assolutamente libero consenso). Sekretariat Stanu uznał za niedozwolone korzystanie przez przełożonych zakonnych czy diecezjalnych z wiedzy psychologicznej dotyczącej ich podwładnych, jeśli nie wyrazili oni uprzednio świadomej zgody. Po drugie, Sekretariat Stanu stwierdził, że bez świadomej zgody zainteresowanych, psychologowi nie wolno udostępniać jakimkolwiek osobom trzecim - niezależnie od ich funkcji religijnych czy politycznych - wiedzy uzyskanej w trakcie badań i dotyczącej osób badanych.

W 1995 roku na Sesji Plenarnej Kongregacji Wychowania Katolickiego zgłoszono konieczność zbadania problemu stosowania testów psychologicznych przy przyjmowaniu kandydatów do seminariów i nowicjatów. Trzy lata później, na Sesji Plenarnej tej samej Kongregacji w 1998 roku została zaprezentowana pierwsza wersja robocza dokumentu pt. Badania psychologiczne i korzystanie $z$ psychologii

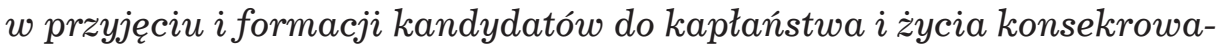
nego (Lo screening psicologico e l'uso della psicologia nell'ammissione e nella formazione dei candidati al sacerdozio e alla vita consacrata). 
Teologia pastoralna

Dokument spotkał się ze słowami uznania oraz krytyki. Autorzy tego opracowania wzywali przede wszystkim do roztropności, gdy chodzi o naturę egzaminu psychologicznego i rodzaje stosowanych testów. W dyskusji nad wersją roboczą zwrócono uwagę na konieczność doprecyzowania, jaką rolę ma odgrywać badanie psychologiczne w formacji do kapłaństwa i życia zakonnego? W 1998 roku na Sesji Plenarnej Kongregacji Wychowania Katolickiego przyjęto wspólne stanowisko w tej sprawie: tego rodzaju dokument jest potrzebny, ale trzeba go koniecznie udoskonalić.

W latach 2000-2002 tekst został poddany pod ocenę różnych ekspertów. Wiele dykasterii Kurii Rzymskiej zostało poproszonych o zgłaszanie swoich uwag i sugestii. Większość propozycji została włączona do tekstu roboczego. W sposób szczególny uwzględniono uwagi przedstawione przez Kongregację Nauki Wiary. Dokument poprawiony został przedstawiony na Sesji Plenarnej Kongregacji Wychowania katolickiego w 2002 roku. W trakcie dyskusji głos zabrał m.in. kard. Joseph Ratzinger, ówczesny prefekt Kongregacji Nauki Wiary, który wyraził swoją pozytywną ocenę dokumentu i podkreślił, że może być on bardzo pomocny w rozumieniu problemów duszy kandydatów do kapłaństwa i życia zakonnego na etapie dojrzewania ich powołania.

W październiku 2002 roku rozpoczęto dalsze konsultacje zainteresowanych dykasterii Kurii Rzymskiej. W lipcu 2004 roku dokument został ponownie przesłany do Sekretariatu Stanu i do innych Kongregacji Stolicy Apostolskiej. Kolejny raz, po naniesieniu poprawek, dokument wszedł pod obrady na Sesji Plenarnej Kongregacji Wychowania Katolickiego w 2005 roku. Dokument został ostatecznie przyjęty na Sesji Plenarnej Kongregacji Wychowania Katolickiego w styczniu 2008 roku. Wyniki głosowania były następujące: 23 głosy placet, 1 głos non placet i 5 głosów placet iuxta modum.

13 czerwca 2008 roku Ojciec Święty Benedykt XVI zatwierdził dokument i polecił jego publikację ${ }^{17}$. 30 października 2008 roku dokument

17 „Il 12 giugno 2006, il Dicastero ha affidato ad uno dei suoi Consultori la bozza del documento presentata alla Plenaria 2005, con le osservazioni dei Padri e delle diverse Congregazioni. Il testo rielaborato è intitolato Orientamenti per l'utilizzo della psicologia nell'ammissione e nella formazione dei candidati al sacerdozio, contenente i suggerimenti dei Dicasteri interessati, è stato presentato alla Plenaria del gennaio 2008. I Padri l'hanno ritenuto maturo, valido e utile; l'hanno approvato chiedendone la pubblicazione con 23 placet, 1 non placet e 5 placet juxta modum. Avendo accolto e inserito le ultime osservazioni dei Padri, il Card. Zenon Grocholewski, Prefetto della Congregazione per l'Educazione Cattolica, il 13 giugno 2008, nel corso dell'Udienza concessa dal Sommo Pontefice Benedetto XVI, ha presentato il documento chiedendo al Papa la conferma del testo e la possibilità di pubblicarlo. Il Santo Padre ha confermato il suddetto 
Zasady korzystania $\mathrm{z}$ dorobku psychologii $\mathrm{w}$ procesie przyjmowania kandydatów $i$ ich formacji do kapłaństwa - po czterdziestu latach przygotowań - został oficjalnie zaprezentowany w Rzymie. Prezentacji jakże długiej historii prac nad tym dokumentem dokonał ówczesny sekretarz Kongregacji Wychowania Katolickiego, francuski dominikanin abp Jean-Louis Bruguès - od 2012 roku archiwista Tajnych Archiwów Watykanu oraz bibliotekarz Biblioteki Watykańskiej ${ }^{18}$. Dokument z 2008 roku potwierdza rozstrzygnięcia Sekretariatu Stanu z 1975 roku i stanowi kompleksowe opracowanie na temat wykorzystania psychologii i psychoterapii w przygotowaniu kandydatów do kapłaństwa i życia zakonnego oraz w chrześcijańskim życiu religijnym tout court.

Teologia pastoralna

\section{Religia i psychomanipulacja}

Pod koniec marca 2015 roku media ogólnopolskie szeroko informowały opinię publiczną o trzydniowych rekolekcjach wielkopostnych w Gryficach (woj. zachodniopomorskie), które prowadziła Szkoła Nowej Ewangelizacji z Koszalina ${ }^{19}$. W rekolekcjach brało udział ok. 1000 uczniów szkół gimnazjalnych i ponadgimnazjalnych z powiatu gryfickiego. Podczas spotkania niektórzy młodzi uczestnicy zanosili się płaczem, a nawet mdleli. Gdy już uczniowie podnosili się z ziemi sami, zachowywali się dziwnie: zataczali się, wybuchali histerycznym śmiechem czy płaczem. Rekolekcje wielkopostne w Gryficach rodzą wiele pytań etycznych związanych m.in. ze stosowaniem technik psychomanipulacyjnych.

Różne formy psychomanipulacji w życiu religijnym chrześcijan łączą się w ostatnich latach z ogólnoświatowym procesem tzw. pentekostalizacji katolicyzmu i chrześcijaństwa w wymiarze planetarnym. Pentekostalizację (ang. Pentecostalization, niem. die Pentekostalisierung, wł. pentecostalizzazione) można określić jako

documento senza porre alcun problema, notando che un solo voto contrario non può essere ostacolo alla pubblicazione" (ibidem).

18 Por. J.-L. Bruguès, Conferenza Stampa di presentazione del documento della Congregazione per l'Educazione Cattolica: „Orientamenti per l'utilizzo delle competenze psicologiche nell'ammissione e nella formazione dei candidati al sacerdozio", Aula Giovanni Paolo II della Sala Stampa della Santa Sede, 30 ottobre 2008 - http://www.vatican.va/roman_curia/congregations/ccatheduc/ documents/rc_con_ccatheduc_doc_20081030_conf-orientamenti_it.html(dostęp: 14.07.2015).

19 Por. M. Kokolus, Horror w Gryficach. Rekolekcje jak egzorcyzmy. Dzieci mdlaty przymodlitwie, ,Fakt”26.03.2015-http://www.fakt.pl/wydarzenia/podczas-rekolekcji-w-gryficach-gimnazjalisci-plakali-i-tracili-przytomnosc,artykuly, 533964. html (dostęp: 14.07.2015). 
Teologia pastoralna

niezwykle szybki wzrost liczebny różnego rodzaju wspólnot stricte zielonoświątkowych oraz proces stopniowego przekształcania wielu innych chrześcijańskich kościołów i związków wyznaniowych w jedną uniwersalną odmianę chrześcijaństwa charyzmatycznego w wymiarze globalnym ${ }^{20}$.

Globalny proces pentekostalizacji można także nazwać „ucharyzmatycznieniem" chrześcijaństwa (niem. die Charismatisierung des Christlichen) bądź ,uzielonoświątkowieniem” (niem. die Verpfingstkirchlichung) religii chrześcijańskiej, albo narodzinami chrześcijaństwa pentekostalnego, charyzmatycznego lub ewangelikalnego.

Pentekostalizacja dotyczy również wielu wspólnot i środowisk katolickich w Polsce. Obecnie mamy do czynienia - także nad Wisłą - z tzw. trzecią falą rozwoju ruchu pentekostalnego. Charakteryzuje się ona szczególnie intensywną manifestacją znaków i cudów, która oznacza

fizyczne uzdrowienia, uwolnienia od demonów i inne somatyczne manifestacje mocy, które przejawiały się np. przez często zbiorowe padanie na podłogę, histeryczny śmiech i różnego rodzaju konwulsje. Ten sposób praktykowania duchowości wywarł duży wpływ na styl spotkań odbywających się również w Polsce ${ }^{21}$.

Neopentekostalizm trzeciej fali przekazuje wiernym to, co święte zasadniczo nie poprzez Biblię - jak czynił to klasyczny pentekostalizm - ale przez święte symbole jak namaszczenie olejem, nałożenie rąk, palenie karteczek z prośbami modlitewnymi, różnego rodzaju egzorcyzmy, uwalnianie od złych duchów itp. Stosowane dzisiaj bardzo często w Polsce przez setki tysięcy katolików - pod wpływem religijności neopentekostalnej trzeciej fali - tzw. nowe sakramentalia (woda egzorcyzmowana, sól egzorcyzmowana i olej egzorcyzmowany) są środkami, które mają pomagać w przepędzaniu mocy złych duchów i chronić ludzi przed wpływem sił demonicznych.

Jako naganne moralnie należy ocenić wszelkie formy psychomanipulacji, stosowane w wielu religiach - w tym także podczas niektórych spotkań charyzmatycznych i zielonoświątkowych w wielu krajach

20 A.Kobyliński,Etycznewymiary wspótczesnejpentekostalizacjichrześcijaństwa, „Studia Philosophiae Christianae” 50 (2014) 3, s. 94. Por. W. J. Hollenweger, Charismatisch-pfingstliches Christentum. Herkunft, Situation, ökumenische Chancen, Göttingen 1997; D. Martin, Tongues of Fire: The Explosion of Protestantism in Latin America, Boston 1993; idem, Pentecostalism: The World Their Parish, Boston 2001; S. M. Studebaker (red.), Pentecostalism and Globalization: The Impact of Globalization on Pentecostal Theology and Ministry, Eugene 2011.

21 A. Migda, Mistycyzm pentekostalny $w$ Polsce, Kraków 2013, s. 169. Por. idem, Stużba uwolnienia $w$ Kościołach i wspólnotach nurtu zielonoświątkowego w Polsce, Stanisławów Pierwszy 2010, s. 21-45. 
świata. W ten sposób narusza się prywatność ludzi oraz ich wolność, co może niekiedy prowadzić do różnych form zniewolenia, uzależnienia lub rozbicia psychicznego.

Wydaje się, że analogicznie do relacji lekarz-pacjent, także w relacji liderów charyzmatycznych do członków wspólnot religijnych powinna obowiązywać zasada świadomej zgody (ang. informed consent), tzn. liderzy stosujący podczas spotkań modlitewnych różnego rodzaju techniki oddziałujące na świadomość lub podświadomość uczestników, powinni mieć obowiązek uprzedniego przekazania im jak najbardziej rzetelnych informacji, które mogą stać się podstawą podjęcia przez nich świadomej zgody na udział w tego rodzaju spotkaniach ${ }^{22}$.

Jaskrawym działaniem psychomanipulacyjnym i zdecydowanie nagannym moralnie jest stosowanie obecnie w wielu chrześcijańskich wspólnotach religijnych tzw. Toronto Blessing, nazywanego także „darem śmiechu". Istotą Toronto Blessing jest wywoływanie u uczestników spotkań modlitewnych dziwnych form histerycznego śmiechu lub wprowadzanie ich w różne rodzaje transu czy histerii. Ruch Toronto Blessing narodził się w 1994 roku w kanadyjskim zborze Toronto Airport Christian Fellowship, należącym do rodziny Kościołów Vineyard ${ }^{23}$.

Pomimo tego, że w wielu środowiskach charyzmatycznych uznano Toronto Blessing za przejaw oszustwa ze strony złych mocy i działalność demoniczną, także dzisiaj w wielu krajach na świecie liderzy pentekostalni wywołują u swoich słuchaczy m.in. ataki histerycznego, niepohamowanego śmiechu lub płaczu, stany „upojenia w duchu” polegające na utracie wszelkiej kontroli nad ciałem i mową, aż po wydawanie przez uczestników tego typu nabożeństw zwierzęcych odgłosów (np. świni, psa, lwa, koguta itp.), które rzekomo są darem Boga i mają prorocze znaczenie ${ }^{24}$.

\section{Podsumowanie}

Roztropne korzystanie z wiedzy psychologicznej i stosowanie adekwatnych modeli psychoterapii jest dzisiaj niezwykle potrzebne. Dotyczy to także różnego rodzaju środowisk katolickich w naszym A. Kobyliński, Etyczne wymiary..., op. cit., s. 120.

Por. J. A. Beverley, Holy Laughter and the Toronto Blessing: An Investigative Report, Michigan 1995; St. Jebb, Nie do śmiechu, tłum. E. Modnicka, Toruń 1996; M. M. Poloma, Toronto Blessing, [w:] St. M. Burgess, E. M. van der Maas (red.), The New International Dictionary of Pentecostal and Charismatic Movements, Michigan 2002, s. 1149-1152; J. Bowker, Toronto Blessing, [w:] The Concise Oxford Dictionary of World Religions, Oxford 2008, s. 754. 
kraju: duszpasterstwa parafialnego, ruchów religijnych, poradni życia rodzinnego, formowania kandydatów do kapłaństwa i życia zakonnego. Wykorzystanie psychologii i psychoterapii musi się jednak łączyć koniecznie z przestrzeganiem podstawowych zasad etycznych ${ }^{25}$.

Wiele cennych rozstrzygnięć w tej dziedzinie zawiera dokument Kongregacji Wychowania Katolickiego z 2008 roku, którego przygotowanie zajęło ok. czterdziestu lat. W oparciu o ten dokument należy eliminować różnego rodzaju nadużycia, jakie pojawiają się m.in. w niektórych seminariach duchownych czy zakonach. Warto pamiętać

o tym, że osoby poddane badaniom psychologicznym mają zawsze pełne prawo do poznania wyników swoich badań. Niestety, czasami wyniki takich badań znają bardziej przełożeni niż sami zainteresowani. Psychologowi, który przeprowadza badania, nie wolno w żaden sposób przekazywać wiedzy na temat osób badanych, jeśli nie wyraziły one swojej zgody na taką praktykę. Odrębną kwestią, która wymaga regulacji jest bezpieczna archiwizacja wyników badań psychologicznych oraz ochrona danych osobowych kleryków, nowicjuszy i sióstr zakonnych, poddawanych badaniom psychologicznym w polskich seminariach duchownych, zakonach, nowicjatach i domach formacyjnych.

Dokument Kongregacji Wychowania Katolickiego z 2008 roku stwierdza, że psychoterapia powinna być prowadzona poza seminarium czy domem zakonnym. Niestety, w naszym kraju czasami poddaje się psychoterapii kleryków czy nowicjuszki w trakcie ich pobytu w seminarium czy domu formacyjnym. Może to prowadzić do negatywnych skutków - jednym z nich mogą być np. niepotrzebne konflikty w życiu wspólnotowym, spowodowane tym, że osoby uczestniczące w psychoterapii są czasami pobudzone lub rozbite emocjonalnie i w trakcie trwania terapii nie potrafią się odnaleźć we wspólnocie seminaryjnej czy zakonnej.

Poważnym wyzwaniem w niektórych środowiskach katolickich w Polsce jest stosowanie adekwatnych modeli psychoterapii, dopasowanych do potrzeb i oczekiwań pacjentów. Wydaje się, że czasami psychoterapia psychoanalityczna może przynieść w życiu religijnym więcej szkody niż pożytku. Chyba nie zawsze trzeba szukać najgłębszych podświadomych uwarunkowań wszystkich naszych zachowań. Czasami z niektórymi skłonnościami czy predyspozycjami, które nie są szczególnie niebezpieczne, trzeba po prostu żyć i nad nimi panować - ucząc się cierpliwie kontroli nad całym swoim bytowaniem. W wielu sytuacjach praca nad sobą powinna być ukierunkowana nie tyle na

25 Por. J. D’Arms, D. Jacobson (red.), Moral Psychology and Human Agency: Philosophical Essays on the Science of Ethics, Oxford 2015. 
eliminowanie niektórych elementów swojej osobowości, ile na głębsze rozumienie siebie i panowanie nad tym, co jest w nas niewłaściwe, ale stanowi część naszego jestestwa. W tym przypadku niezwykle pomocna jest koncepcja antropologiczna Romana Guardiniego, który mówił o człowieku jako jedności i harmonii przeciwieństw. Szkoda, że wielkie dzieło niemieckiego filozofa i teologa jest tak słabo wykorzystywane w różnego rodzaju środowiskach katolickich w Polsce.

Szczególnie aktualnym wyzwaniem jest dzisiaj respektowanie zasad etycznych w kontekście nowych form psychomanipulacji, jakie pojawiają się obecnie w różnych formach życia religijnego. Pod żadnym pretekstem nie wolno wykorzystywać wiedzy psychologicznej do psychomanipulacji i przejmowania władzy psychicznej nad członkami grup religijnych. Należy za wszelką cenę eliminować różne formy nadużyć w tym zakresie. Wydaje się, że stosowanie w wielu środowiskach katolickich w Polsce tzw. upadków czyli spoczynku w duchu w niektórych przypadkach w jakiś sposób uzależnia psychicznie i emocjonalnie ludzi, którzy tego doświadczają od tych, którzy stosują wobec nich takie metody.

Wydaje się, że ksiądz katolicki, który zastosował choć raz wobec swoich penitentów tzw. spoczynek w duchu, nie powinien być już dla nich spowiednikiem czy kierownikiem duchowym - jeśli chcemy zachować zasadę wolności penitenta w stosunku do spowiednika czy kierownika duchowego. Niestety, w języku polskim nie ma żadnych opracowań naukowych na ten temat. Zagadnienie wymaga niewątpliwie dalszych pogłębionych badań interdyscyplinarnych z pogranicza antropologii, etyki, psychologii, teologii czy prawa kanonicznego.

Stosowanie różnych dziwnych praktyk religijnych, np. wprowadzania ludzi w tzw. odmienne stany świadomości czy łączenie histerycznego śmiechu z adoracją Najświętszego Sakramentu, powinno zawsze zakładać zasadę świadomej zgody. Zasada świadomej zgody i odpowiedzialności rodziców bądź opiekunów prawnych - analogicznie jak w medycynie - powinna w sposób szczególny dotyczyć osób nieletnich, ponieważ bardzo często to właśnie osoby poniżej 18. roku życia padają ofiarą psychomanipulacji ze strony różnych liderów religijnych.

Słowa kluczowe: antropologia, metody psychoanalityczne, pentekostalizacja, psychologia głębi, psychomanipulacja, zasady etyczne.

\section{Bibliografia:}

1. Aletti M. (red.), Psicologia della religione. Prospettive psicosociali ed empiriche, Torino 2001. 
Teologia pastoralna

2. Aletti M., Il senso religioso e la psicologia della religione. Decostruire un concetto, elaborare un metodo, proporre strumenti, [w:] M. T. Moscato, R. Gatti, M. Caputo (red.), Crescere tra vecchi e nuovi dei. L'esperienza religiosa in prospettiva multidisciplinare, Roma 2012.

3. Belzen J. A., Religionspsychologie. Eine historische Analyse im Spiegel der Internationalen Gesellschaft, Berlin - Heilderberg 2015.

4. Beverley J. A., Holy Laughter and the Toronto Blessing: An Investigative Report, Michigan 1995.

5. Biser E., Chi era Romano Guardini? Domande rivolte a una risposta, [w: S. Zucal (red.), Romano Guardini e la sua visione cristiana del mondo, Padova 1989.

6. Börsig-Hover L., Das personale Antliz des Menschen. Eine Untersuchung zum Personbegriff bei Romano Guardini, Mainz 1987.

7. Bowker J., Toronto Blessing, [w:] The Concise Oxford Dictionary of World Religions, Oxford 2008.

8. Bruguès J.-L., Conferenza Stampa di presentazione del documento della Congregazione per l'Educazione Cattolica: „Orientamenti per l'utilizzo delle competenze psicologiche nell'ammissione e nella formazione dei candidati al sacerdozio", Aula Giovanni Paolo II della Sala Stampa della Santa Sede, 30 ottobre 2008 - http://www.vatican.va/roman_curia/congregations/ ccatheduc/documents/rc_con_ccatheduc_doc_20081030_conf-orientamenti_it.html (dostęp: 14.07.2015).

9. D’Arms J., Jacobson D. (red.), Moral Psychology and Human Agency: Philosophical Essays on the Science of Ethics, Oxford 2015.

10. De Simone S., Premesse e promesse dell'esperienza credente cristiana. Una ricomprensione dell',Analysis fidei” a partire dal rapporto tra teologia della grazia e psicologia, Assisi 2015.

11. Dudek Z. W., Podstawy psychologii Junga, Warszawa 2009.

12. Egenolf P., Vocation and Motivation. The Theories of Luigi Rulla, „The Way" 42 (2003) 3.

13. Grom B., Religionspsychologie, München 2007.

14. Guardini R., Ethik. Vorlesungen an der Universität München (1950-1962), t. I, Mainz - Padeborn 1993.

15. Guardini R., Lesistenza del cristiano, Milano 1977.

16. Hollenweger W. J., Charismatisch-pfingstliches Christentum. Herkunft, Situation, ökumenische Chancen, Göttingen 1997.

17. Howard E. B., Affirming the Touch of God: A Psychological and Philosophical Exploration of Christian Discernment, Lanham 2000.

18. Jebb S., Nie do śmiechu, tłum. E. Modnicka, Toruń 1996.

19. Kobyliński A., Etyczne wymiary współczesnej pentekostalizacji chrześcijaństwa, „Studia Philosophiae Christianae” 50 (2014) 3.

20. Kokolus M., Horror w Gryficach. Rekolekcje jak egzorcyzmy. Dzieci mdlaty przy modlitwie, „Fakt” 26.03.2015 - http:/www.fakt.pl/wydarzenia/podczas-rekolekcji-w-gryficach-gimnazjalisci-plakali-i-tracili-przytomnosc,artykuly,533964.html (dostęp: 14.07.2015).

21. Lämmermann G., Einführung in die Religionspsychologie, Neukirchen-Vluyn 2006. 
22. Lonergan B., Insight: A Study of Human Understanding, t. I-III, Toronto 1992.

23. Magnani G., La crisi della metapsicologia freudiana, Roma 1981.

24. Martin D., Pentecostalism: The World Their Parish, Boston 2001.

25. Martin D., Tongues of Fire: The Explosion of Protestantism in Latin America, Boston 1993.

26. McGuire P., Jak ewangelizować New Age? Torun 1995.

27. Migda A., Mistycyzm pentekostalny w Polsce, Kraków 2013.

28. Migda A., Stużba uwolnienia w Kościołach i wspólnotach nurtu zielonoświątkowego w Polsce, Stanisławów Pierwszy 2010.

29. Morgalla S., Dojrzałość osobowościowa i religijna. Luigi Maria Rulla i jego teorie psychologiczne oraz poglądy antropologiczne, Kraków 2006.

30. Papieska Rada ds. Kultury, Papieska Rada ds. Dialogu Międzyreligijnego, Jezus Chrystus dawca wody żywej. Refleksja chrześcijańska nt. New Age, Poznań 2003.

31. Poloma M. M., Toronto Blessing, [w:] S. M. Burgess, E. M. van der Maas (red.), The New International Dictionary of Pentecostal and Charismatic Movements, Michigan 2002.

32. Prada Ramirez J. R., Psicologia e formazione. Principi psicologici utilizzati nella formazione per il sacerdozio e la vita consacrata, Roma 2009.

33. Rulla L., Antropologia della vocazione cristiana, t. I, Basi interdisciplinari, Bologna 1986.

34. Rulla L., Antropologia della vocazione cristiana, t. II, Conferme esistenziali, Bologna 1989

35. Rulla L., Antropologia della vocazione cristiana, t. III, Aspetti interpersonali, Bologna 1998.

36. Rulla L., Depth psychology and vocation. A psicho-social perspective, Roma 1971.

37. Schilson A., Welt und Person. Der geistesgeschichtliche Hintergrund. Perspektiven der Antropologie zu Beginn des 20 Jahrhunderts, „Burgbrief” (1991) 3.

38. Studebaker S. M. (red.), Pentecostalism and Globalization: The Impact of Globalization on Pentecostal Theology and Ministry, Eugene 2011.

39. Valerio A., Diventa ciò che sei. Un cammino di psicospiritualità cristiana, Cinisello Balsamo 2005.

40. Vial W., Psicologia e vita cristiana. Cura della salute mentale e spirituale, Roma 2012. 